\title{
Airborne observations of formic acid using a chemical ionization mass spectrometer
}

\author{
M. Le Breton ${ }^{1}$, M. R. McGillen ${ }^{1,}$, J. B. A. Muller ${ }^{1}$, A. Bacak ${ }^{1}$, D. E. Shallcross ${ }^{2}$, P. Xiao ${ }^{2}$, L. G. Huey ${ }^{3}$, D. Tanner ${ }^{3}$, \\ H. Coe ${ }^{1}$, and C. J. Percival ${ }^{1}$ \\ ${ }^{1}$ Centre for Atmospheric Science, School of Earth, Atmospheric and Environmental Science, University of Manchester, \\ Oxford Road, Manchester, M13 9PL, UK \\ ${ }^{2}$ Biogeochemistry Research Centre, School of Chemistry, University of Bristol, Cantock's Close, Bristol, BS8 1TS, UK \\ ${ }^{3}$ School of Earth and Atmospheric Sciences, Georgia Institute of Technology, Atlanta, Georgia, USA \\ * currently at: Chemical Sciences Division, Earth System Research Laboratory, National Oceanic and Atmospheric \\ Administration (NOAA), 325 Broadway, Boulder, CO 80305, USA
}

Correspondence to: C. J. Percival (c.percival@manchester.ac.uk)

Received: 5 August 2011 - Published in Atmos. Meas. Tech. Discuss.: 14 September 2011

Revised: 26 October 2012 - Accepted: 27 October 2012 - Published: 7 December 2012

\begin{abstract}
The first airborne measurements of formic acid mixing ratios over the United Kingdom were measured on the FAAM BAe-146 research aircraft on 16 March 2010 with a chemical ionization mass spectrometer using $\mathrm{I}^{-}$reagent ions. The $\mathrm{I}^{-}$ionization scheme was able to measure formic acid mixing ratios at $1 \mathrm{~Hz}$ in the boundary layer.

In-flight standard addition calibrations from a formic acid source were used to determine the instrument sensitivity of $35 \pm 6$ ion counts $\mathrm{pptv}^{-1} \mathrm{~s}^{-1}$ and a limit of detection of 25 pptv. Routine measurements were made through a scrubbed inlet to determine the instrumental background. Three plumes of formic acid were observed over the UK, originating from London, Humberside and Tyneside. The London plume had the highest formic acid mixing ratio throughout the flight, peaking at 358 pptv. No significant correlations of formic acid with $\mathrm{NO}_{\mathrm{x}}$ and ozone were found, but a positive correlation was observed between $\mathrm{CO}$ and $\mathrm{HCOOH}$ within the two plumes where coincident data were recorded.

A trajectory model was employed to determine the sources of the plumes and compare modelled mixing ratios with measured values. The model underestimated formic acid concentrations by up to a factor of 2 . This is explained by missing sources in the model, which were considered to be both primary emissions of formic acid of mainly anthropogenic origin and a lack of precursor emissions, such as isoprene, from biogenic sources, whose oxidation in situ would lead to formic acid formation.
\end{abstract}

\section{Introduction}

Organic acids are ubiquitous in the gas and aerosol phase, common constituents of global precipitation (Keene et al., 1983) and are measured in urban, rural and remote areas (Talbot et al., 1988). The contribution of organic acids to the acidity of precipitation and subsequent effects on aquatic and terrestrial ecosystems has been documented by Keene and Galloway (1986). Formic ( $\mathrm{HCOOH})$ acid can dominate free acidity of precipitation, thereby having an influence on $\mathrm{pH}$ dependent chemical reactions and $\mathrm{OH}$ cloud chemistry (Jacob, 1986). Low molecular weight organic salts are present in the fine fraction of aerosols, whose physical properties, namely hygroscopicity, include relatively low critical supersaturations, allowing the activation of cloud droplets to occur and subsequently affecting the total indirect forcing ( $\mathrm{Yu}$, 2000).

Sources of formic acid include biogenic and anthropogenic primary emissions, e.g. biomass burning (Burling et al., 2010) and in situ production such as hydrocarbon oxidation, though their relative fluxes are poorly constrained (Chebbi and Carlier, 1996). The major sinks of saturated carboxylic acids are dry and wet deposition as a result of their low reactivity towards $\mathrm{OH}$ and $\mathrm{NO}_{3}$. Sanhueza and Andreae (1991) and Hartmann et al. (1991) have shown that forests (acetic acid dominating) and particularly savanna regions (formic acid dominating) in Venezuela are strong sources of formic and acetic acid. These are thought to be 
in part from direct emission by plants, but are dominated by in situ production following ozonolysis of alkenes (Sanhueza et al., 1996), where savanna levels for both species peaked around midday with a level of around $1 \mathrm{ppbv}$. Grosjean (1992) observed high levels of formic at a site in Southern California close to a coastal area, here direct emissions of acetic acid dominated over formic acid by a factor of 2 , peaking in the summer at 20.4 and 9.6 metric tons per day, respectively. It was concluded that in situ production was of similar magnitude, with formic acid dominating over acetic acid (25.0 and 10.1 metric tons per day rising to 34.5 for formic acid but dropping for acetic acid to 4.3 at night). Preunkert et al. (2007) also concluded that in situ production was the dominant process for formic and acetic acid production in Europe, based on high-altitude measurements. However, these in situ production rates are based on earlier product data for acid formation from the ozonolysis of alkenes; more recent data (Leather et al., 2012) would suggest that the in situ production has been overestimated.

Johnson and Dawson (1993) carried out ${ }^{13} \mathrm{C}$ and ${ }^{14} \mathrm{C}$ analysis from background sites in the USA and concluded that direct emission of formic acid from $\mathrm{C}_{3}$ plants was the most likely dominant source. Biomass burning is also a significant source of formic and acetic acid (Dibb et al., 1996; Talbot et al., 1999; Zhong et al., 2001). In Sao Paolo, Fornaro and Gutz (2003) concluded that high acetic acid resulted from direct emissions from ethanol fuelled cars, whilst high formic acid came from in situ production. Ocean sources of these organic acids have been suggested by Baboukas et al. (2000).

Gas-phase concentrations of formic acid in particular have been measured in the low ppb ranges (Talbot et al., 1999), and the modelled atmospheric lifetime has been suggested to be 3.2 days (Paulot et al., 2011). Global models underpredict formic acid budgets (von Kuhlmann et al., 2003; Rinsland et al., 2004; Paulot et al., 2011) by up to a factor of 50 in marine locations. Such discrepancies between perceived source strengths and observed atmospheric concentrations have led many authors to speculate upon the existence of a missing or poorly constrained source term (e.g. Grosjean and Seinfeld, 1989; Talbot et al., 1988, 1995; Granby et al., 1997; Rinsland et al., 2004), and it has been suggested by several of these studies that an unknown anthropogenic, and perhaps secondary source may be responsible, such as higher biogenic emissions during the growing season (Rinsland et al., 2004) and ageing of organic aerosols (Paulot et al., 2011). Also, the oxidation of volatile organic compound (VOC) precursors leading to the production of formic acid has been suggested as a significant source (Arlander et al., 1990), for instance the ozonolysis of ethene, whose emissions have been estimated to be $15 \mathrm{Tg} \mathrm{yr}^{-1}$ (Broadgate et al., 1997; Paulot et al., 2011).

Proton transfer reaction mass spectrometry has been used for the detection of organic acids, but has a limit of detection (LOD) of the order of a ppb (de Gouw et al., 2003). However, negative ion chemical ionization mass spectrometry
(NI-CIMS) has proven to be a powerful method for sensitive and selective measurements of organic acids at the ppt level (Amelynck et al., 2000; Crounse et al., 2006; Paulot et al., 2009a, b). More recently, Veres et al. (2008), Roberts et al. $(2010,2011)$ and Bertram et al. (2011) have shown that chemical ionization mass spectrometry can be used to selectively detect gas-phase organic acids with a limit of detection below $0.1 \mathrm{ppbv}$ for $1 \mathrm{~s}$ measurements of formic acid. Veres et al. (2008) report a limit of detection of 80-90 pptv and sensitivity of 24 ion counts s ${ }^{-1} \mathrm{pptv}^{-1}$ using the acetate ionization scheme. Roberts et al. (2010) utilised the same technique for measurements of formic acid and other inorganic acids such as HONO. Although the sensitivity to formic acid is not quoted, the sensitivity for HNCO of 16 ion counts $\mathrm{s}^{-1} \mathrm{pptv}^{-1}$ is reported. The rapid time response of CIMS is particularly well suited for airborne measurements, and this study focuses on the development of a negative ion chemical ionization mass spectrometer (CIMS) utilising $\mathrm{I}^{-}$as a method for the on-line measurement of carboxylic acids on an airborne platform.

\section{Experimental details}

\subsection{CIMS apparatus}

Chemical ionization mass spectrometry (CIMS) was used for real-time detection of formic acid. The CIMS instrument employed here was built by the Georgia Institute of Technology as previously described by Nowak et al. (2007). The schematic in Fig. 1 shows the setup used and operating conditions of the CIMS on board the FAAM BAe-146 research aircraft.

\subsubsection{Inlet}

The sample air for the CIMS was obtained by sub-sampling from the aircraft air sampling pipe (ASP). The ASP is a ram air inlet consisting of a $6 \mathrm{~cm}$ OD stainless steel pipe, with an internal surface which has been highly electro-polished for inertness. Several $0.6 \mathrm{~cm}$ and $1 \mathrm{~cm}$ OD Swagelok ports are welded to the ASP, separated by $\sim 8.9 \mathrm{~cm}$, providing air to instrumentation in the cabin. Pressure measurements in the ASP were conducted at a flight level of $8230 \mathrm{~m}$ with a pitot tube in order to determine the linear air velocity in the ASP during scientific cruise speed, typically 210 knot aircraft-indicated air speed. For an outside static pressure of 261 Torr, the ASP static pressure was 309 Torr, and its ram air pressure was 325 Torr. The derived ASP linear air velocity is $85 \mathrm{~m} \mathrm{~s}^{-1}$. Given an estimated ASP ID of $45 \mathrm{~mm}\left(15.90 \mathrm{~cm}^{2}\right.$ cross-section), the equivalent volumetric flow rate through the ASP is $135 \mathrm{~L} \mathrm{~s}^{-1}$. The sub-sample passed through a $1.3 \mathrm{~cm}$ diameter PFA (perfluoroalkoxy) inlet line that entered the CIMS body through a $8.9 \mathrm{~cm} \mathrm{3-way} \mathrm{valve} \mathrm{(with} \mathrm{inter-}$ nal orifice diameter of $0.63 \mathrm{~cm}$, M-Series Solenoid Valve, TEQCOM). A rotary vane pump (Picolino VTE-3, Gardner 


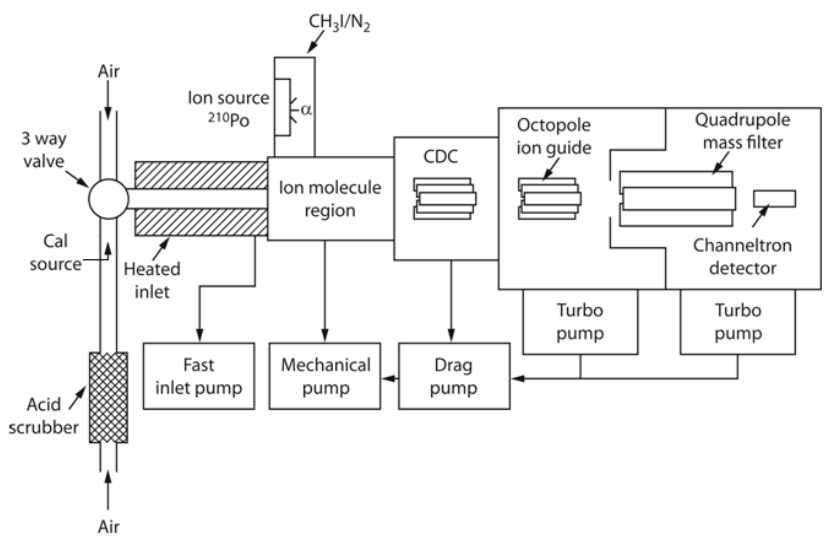

Fig. 1. Schematic of chemical ionization mass spectrometer (CIMS) used in this study. Arrows indicate direction of gas flow. Dimensions are not to scale.

Denver Thomas) allowed a fast inlet flow of $13 \mathrm{~L} \mathrm{~min}^{-1}$, which corresponded to a residence time of $0.7 \mathrm{~s}$ (at standard temperature and pressure) in the total length of inlet tubing. It was not possible to test for loss along the ASP in situ; however, during ground tests only a $3 \%$ loss of $\mathrm{HCOOH}$ was observed for a inlet residence time of $0.8 \mathrm{~s}$. Thus, the impact of the ASP losses are assumed to be negligible as they are smaller than the sum of other systematic errors.

\subsubsection{Ionization region}

Initially the sample passed through a $380 \mu \mathrm{m}$ diameter sized pinhole to reach the ion-molecule region (IMR) where ionization occurred at a pressure of 22 Torr, maintained by a dry scroll backing pump (UL-DISL 100, ULVAC Industrial). Sample flow through the orifice was 0.8 SLM on the ground. The pressure in the ionization region was set and controlled to 22 Torr, and thus the flow through the orifice changes slightly with ambient pressure. Flows were controlled and measured using a mass flow controller (MKS 1179 and MKS M100 Mass flow controllers, MKS Instruments, UK) and Baratron (1000 Torr range, Pressure Transducer, Model No. $722 \mathrm{~A}$, MKS Instruments, UK). At the IMR, $\mathrm{N}_{2}$ was added at a flow rate of $\sim 1.5 \mathrm{SLM}$, and the ionization gas mixture of $\mathrm{CH}_{3} \mathrm{I} / \mathrm{H}_{2} \mathrm{O} / \mathrm{N}_{2}$ at a rate of $1 \mathrm{SCCM}$ passed over the ion source (Polonium-210 inline ionizer, NRD Inc Static Solutions Limited), producing an excess of $\mathrm{I}^{-}$and $\mathrm{I}^{-} \cdot \mathrm{H}_{2} \mathrm{O}$ ions in the IMR, which then ionized the organic acid molecules in the air sample.

\subsubsection{Ion filtration and detection}

The ions are then passed through the pinhole $(600 \mu \mathrm{m})$ of a charged plate, which entered the mass spectrometer section of the instrument, i.e. the first octopole ion guide chamber which is the collisional dissociation chamber (CDC) where weakly bound ion-water clusters are broken up to simplify the resultant mass spectrum. The pressure in the CDC of 0.24 Torr was achieved by the use of a molecular drag pump (MDP-5011, Adixen Alcatel Vacuum Technology). After the $\mathrm{CDC}$, the ions passed through the second octopole ion guide, which has the effect of collimating the ions. The octopole chamber was held at a pressure of $\sim 10^{-3}$ Torr which was maintained by a turbomolecular pump (V-81M Navigator, Varian Inc. Vacuum Technologies). Past the second octopole chamber, the ions were mass selected by a quadrupole with pre- and post-filters with entrance and exit lenses (Tri-filter Quadrupole Mass Filter, Extrel CMS). The quadrupole section was kept at a pressure of $10^{-4}$ Torr by a second turbomolecular pump (V-81M Navigator, Varian Inc. Vacuum Technologies). The selected ions were then detected and counted by a continuous dynode electron multiplier $(7550 \mathrm{M}$ detector, ITT Power Solutions, Inc.).

\subsection{Ionization scheme}

The ion-molecule chemistry using iodide ions $\left(\mathrm{I}^{-}\right)$for trace gas detection has been described by Slusher et al. (2004) and was utilised here to detect organic acids. A gas mixture of methyl iodide, $\mathrm{CH}_{3} \mathrm{I}$, and $\mathrm{H}_{2} \mathrm{O}$ in $\mathrm{N}_{2}$ is prepared by gas expansion and used to obtain reagent ions $\mathrm{I}^{-}$and water clusters $\mathrm{I}^{-} \cdot \mathrm{H}_{2} \mathrm{O}$, of which the latter is important for the ionization of formic acid, forming the acid-iodine adducts as seen in the mass spectrum (Fig. 2). Formic acid was ionized by $\mathrm{I}^{-}$via an adduct reaction,

$\mathrm{I}^{-} \cdot \mathrm{H}_{2} \mathrm{O}_{n}+\mathrm{HCOOH} \rightarrow \mathrm{HCOOH} \cdot \mathrm{I}^{-} \cdot \mathrm{H}_{2} \mathrm{O}_{n}$,

which enabled formic acid to be detected selectively at $m / z=173$. As the ionization efficiency is dependent on the presence of water vapour through the production of $\mathrm{I}^{-} \cdot \mathrm{H}_{2} \mathrm{O}$ (Slusher et al., 2004), water vapour was added to the ionization gas mixture so as to produce an excess of $\mathrm{I}^{-} \cdot \mathrm{H}_{2} \mathrm{O}$ cluster ions and hence allow operation in the water vapour independent regime. The mix was produced using a manifold by evaporating the liquid deionized $\mathrm{H}_{2} \mathrm{O}(\geq 15.0 \mathrm{M} \Omega \mathrm{cm}$, obtained from a PURELAB Option-S 7/15, ELGA) and $\mathrm{CH}_{3} \mathrm{I}$ sequentially into the manifold to reach the partial pressures of 10 Torr $\mathrm{H}_{2} \mathrm{O}$ and 15 Torr $\mathrm{CH}_{3} \mathrm{I}$, before adding 3800 Torr of $\mathrm{N}_{2}$ to make a ionization gas mixture of $0.39 \% \mathrm{CH}_{3} \mathrm{I}$ and $0.26 \% \mathrm{H}_{2} \mathrm{O}$. Methyl iodide $\mathrm{CH}_{3} \mathrm{I}, \geq 99.5 \%$, was purchased from Sigma Aldrich and used as provided. Typical reagent ion values were $\mathrm{I}^{-}=1.5 \times 10^{6} \mathrm{~Hz}$ and $\mathrm{I} \cdot \mathrm{H}_{2} \mathrm{O}=2.5 \times 10^{6} \mathrm{~Hz}$. The pressure in the CDC was 0.25 Torr, where the local electric field divided by the gas number density $(E / N)$ was 180 Townsend $\left(\mathrm{Td}=10^{-17} \mathrm{~V} \mathrm{~cm}^{2}\right)$.

\subsection{Formic acid calibrations, sensitivity and LOD}

Formic acid calibrations were made pre-flight and in-flight. The calibration cycle involves obtaining the formic acid instrumental background by passing the sample air through an acid scrubber which is made of nylon turnings coated with 


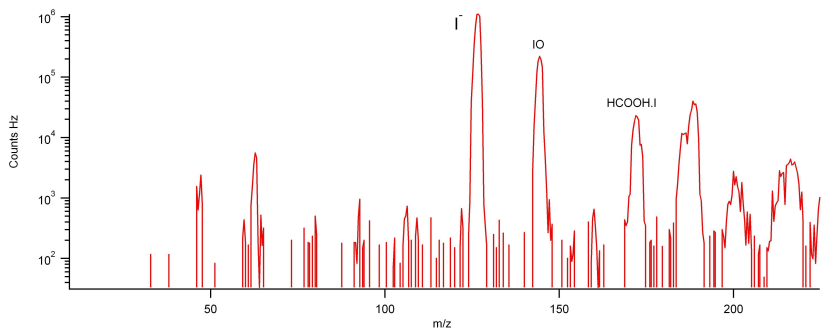

Fig. 2. Mass spectrum of CIMS during flight B518, 16 March 2010 at 16:00. Ionization peaks and formic acid adduct mass are labelled. Peaks at $m / z 190,201,215$ correspond to $\mathrm{HNO}_{3}$, propanoic and butanoic acid, respectively. The FWHM is 1 amu at $m / z=173$.

sodium bicarbonate. After an effective zero acid air flow for background determination, a known amount of formic acid from a pressurised gas cylinder is added to this scrubbed air flow until a plateau in formic acid signal is achieved. A second background determination is carried out before the 3way PFA valve is switched back to atmospheric sampling mode (Fig. 1). The organic acid gas mixture that was used for the in-flight calibrations of the CIMS was analysed by flame ionization detection as follows. A liquid standard of the acid (with toluene added) was diluted and then injected directly onto a gas chromatography-flame ionization detector system (GC-FID ADS). The dilution factor was determined by the dilution of the toluene, referenced to a certified synthetic standard (Apel-Riemer Environment, USA) as outlined by Yates et al. (2010). The in-flight standard was then calibrated against this standard mixture, and the formic acid calibration factor was applied to the relative formic acid concentrations during post-flight data processing. During a test flight, the calibration was proven to be invariant with altitude. Calibrations were performed from 15 to $920 \mathrm{~m}$, and the variation in inlet flow was taken into account. The sensitivity determined from the calibrations at these altitudes were within 3 sigma of the error calculated from the statistical noise of the calibration signal in the plateau region.

The sensitivity of the CIMS to formic acid (in units of counts/ppb of formic acid) was calculated as the ratio of the background corrected formic acid calibration counts to the formic acid absolute calibration factor (in units of ppb). The formic acid signal was normalized for $\mathrm{I} \cdot \mathrm{H}_{2} \mathrm{O}^{-}$counts to remove variance caused by changes in reagent ion signal. For this flight the sensitivity was $35 \pm 6$ ion counts $\mathrm{s}^{-1} \mathrm{pptv}^{-1}$. The $3 \sigma$ limit of detection (LOD) for formic acid was calculated to be 25 pptv. The instrument response time was estimated by adding a known amount of formic acid to the instrument for a given period of time, as shown in Fig. 3. The calibration gas is delivered via a $1 / 8^{\prime \prime}$ diameter PFA tube to the acid-scrubbed air ( $3 / 8^{\prime \prime}$ tubing) about $3 \mathrm{~cm}$ before the 3 way valve. Total inlet flow was measured and no clear difference between background/calibration flow and flow in sampling mode was observed, and the pressure drop across the

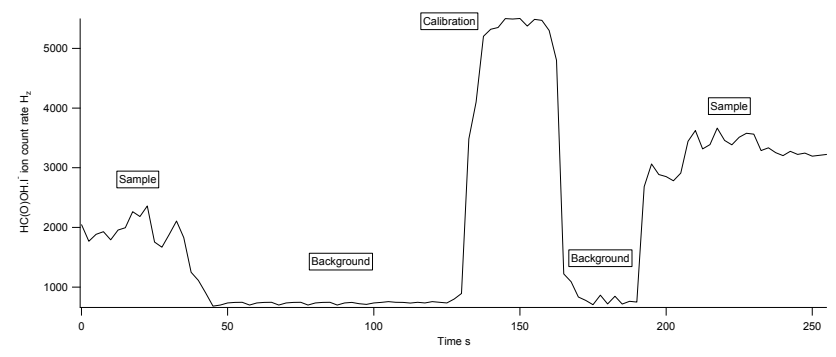

Fig. 3. Typical cycle for background, sampling and calibrations during flight.

scrubber is hence minimal. The instrument has an e-folding time of $1.5 \mathrm{~s}$ and a response time, i.e. the time required for a steady-state signal to decay to $10 \%$ of the initial signal when a background measurement is made (Veres et al., 2008), of $4 \mathrm{~s}$. The background was determined in-flight every sixty minutes. The average difference between consecutive backgrounds was $30 \pm 5$ pptv.

\subsection{Data logging, capture and handling}

The CIMS can count a number of separate masses in sequence; eight here, with a dwell time of $100 \mathrm{~ms}$ each yielding a sampling frequency of $1.67 \mathrm{~Hz}$. Alternatively, spectral scans across the whole mass spectrum can be taken. Spectral scans were performed twice during the flight B518 (Fig. 2). The high-frequency formic acid time series was analysed by removing background counts (averaging to $30 \mathrm{~s}$ ) and calibrating relative counts using the calibration factor obtained during the in-flight calibration cycle (averaging to $30 \mathrm{~s}$ ). The formic acid data capture is $86 \%$ for the whole flight, and the $14 \%$ of data loss is a result of the in-flight calibration and background measurements. Data obtained during transit at $3048 \mathrm{~m}$ (10 000 feet) are not shown as no calibration was performed at this height and calibration altitude independence was only confirmed for heights up to $914 \mathrm{~m}$ (3000 feet, see previous text).

\subsection{FAAM BAe-146 onboard instruments}

In addition to formic acid data, observations of $\mathrm{CO}, \mathrm{NO}_{2}$ and $\mathrm{O}_{3}$ are used in the analysis. Nitric oxide (NO) and nitrogen dioxide $\left(\mathrm{NO}_{2}\right)$ were measured using separate channels of a chemiluminescence detector and were reported every $10 \mathrm{~s}$ with an uncertainty of $\pm 6 \%$ ppbv (Stewart et al., 2008). CO data are reported at $1 \mathrm{~Hz}$ using as fast fluorescence $\mathrm{CO}$ analyser with an uncertainty of $\pm 5 \%$ (Gerbig et al., 1999). Ozone was measured using a UV Photometric Ozone Analyser at $1 \mathrm{~Hz}$ with an uncertainty of \pm 3 ppbv (Real et al., 2007).

\subsection{Trajectory model}

A trajectory model has been used to estimate formic acid concentrations along the B518 flight path. The trajectory 


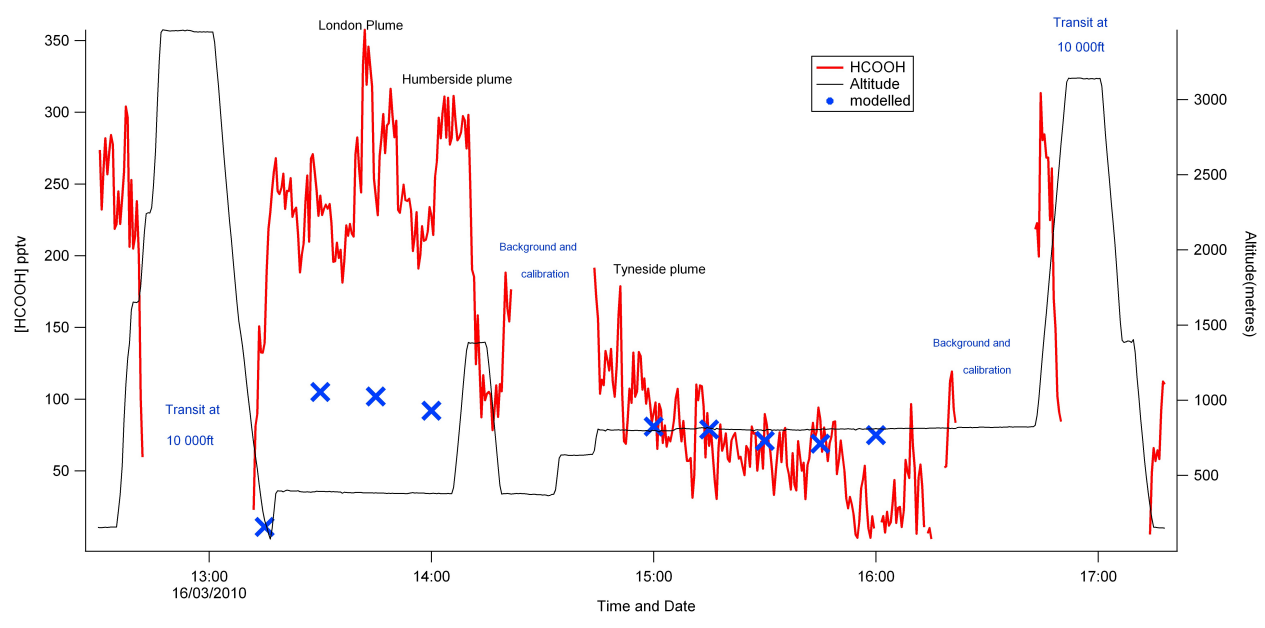

Fig. 4. Time series of 30-s averaged formic acid observations (left axis) with altitude (right axis) from the 16 March 2011 flight. The London, Humberside and Tyneside plumes have been labelled. Sections of the flight where there are backgrounds, calibrations and transits are set to zero, and comparison with back trajectory modelled data is shown.

model used for this purpose has been described in previous papers (Derwent et al., 1991; Derwent and Jenkin, 1996; Johnson et al., 2006a, b; Evans et al., 2000) and will be only briefly described here. The trajectory model simulates the chemical development in a well-mixed air parcel being advected along multi-day trajectories. The air parcel picks up emissions of $\mathrm{NO}_{\mathrm{x}}, \mathrm{CO}, \mathrm{SO}_{2}$, methane, anthropogenic VOC and biogenic VOC when in the boundary layer, which are processed using an appropriate description of the chemical and photochemical transformations leading to the formation of ozone and other secondary pollutants. Dry deposition of species also occurs when the air parcel is in the boundary layer.

Two chemistry modules have been integrated into the trajectory mode: the full Master Chemical Mechanism (MCM v3.1; Jenkin et al., 1997) and the Common Representative Intermediates scheme (CRIv2-R5; Jenkin et al., 2008; Watson et al., 2008; Utembe et al., 2009, 2011a, b; Archibald et al., 2010). Trajectories are generated by the Hysplit model and integrated for four days, arriving at a point coincident in time and space with the aircraft flight track (Draxler and Rolph, 2003).

\subsection{Field conditions for flight B518}

The $1 \mathrm{~Hz}$ formic acid data obtained from takeoff until landing on flight B518, 16 March 2010, enabled observations of plumes from a variety of sources. The measurements were taken over the North Sea, aiming to intercept pollution plumes from the UK carried by a south-south-westerly wind with wind speed of $2.8 \mathrm{~m} \mathrm{~s}^{-1}$. The meteorological conditions for the previous 3 days and the day of the flight were free of precipitation. These conditions favoured the accumulation of carboxylic acids in the vapour phase, since wet deposition would have been reduced.

\section{Analysis and discussion}

\subsection{Observations of formic acid concentrations}

The instrumental sensitivity of $35 \pm 6$ ion counts pptv ${ }^{-1} \mathrm{~s}^{-1}$ is comparable with previously reported measurements of formic acid using CIMS (Veres et al., 2008; Roberts et al., 2010). Formic acid mixing ratios ranged from $34.4 \mathrm{pptv}$ to 358 pptv, as shown in Fig. 4, intersecting 3 separate major plumes during the flight. The mean mixing ratio during the flight was 142.4 pptv, with a 3-sigma standard deviation of $71.9 \mathrm{pptv}$. A comparison with previously reported data is difficult due to its scarcity. Satellite and infrared (IR) measurements have been made, but these are mainly at altitudes greater than $2 \mathrm{~km}$. Zander et al. (2010) reported an average mixing of ratio of $110.9 \mathrm{pptv}$ in the 3.58 to $10.6 \mathrm{~km}$ region, which is comparable to the concentrations reported here. Satellite-based IR measurements have been made to altitudes of $5 \mathrm{~km}$, where mixing ratios of $157 \pm 60$ have been recorded (González Abad et al., 2009), similar to the smaller plumes measured on flight B518. A decrease in mixing ratios with altitude is observed, which is most likely a consequence of the increasing distance from direct and indirect sources which results in the dilution of the original plume material and allows time for loss processes (predominantly depositional) to operate. It is difficult to compare the measurements made here with the current data available due to the possible variances in experimental conditions such as different observational regions, times, altitudes and also measurement techniques.

\subsection{Urban plumes}

Flight B518 intercepted 3 separate plumes of formic acid over the UK. The different plumes detected during the flight were plumes from London, Humberside and Tyneside; these 


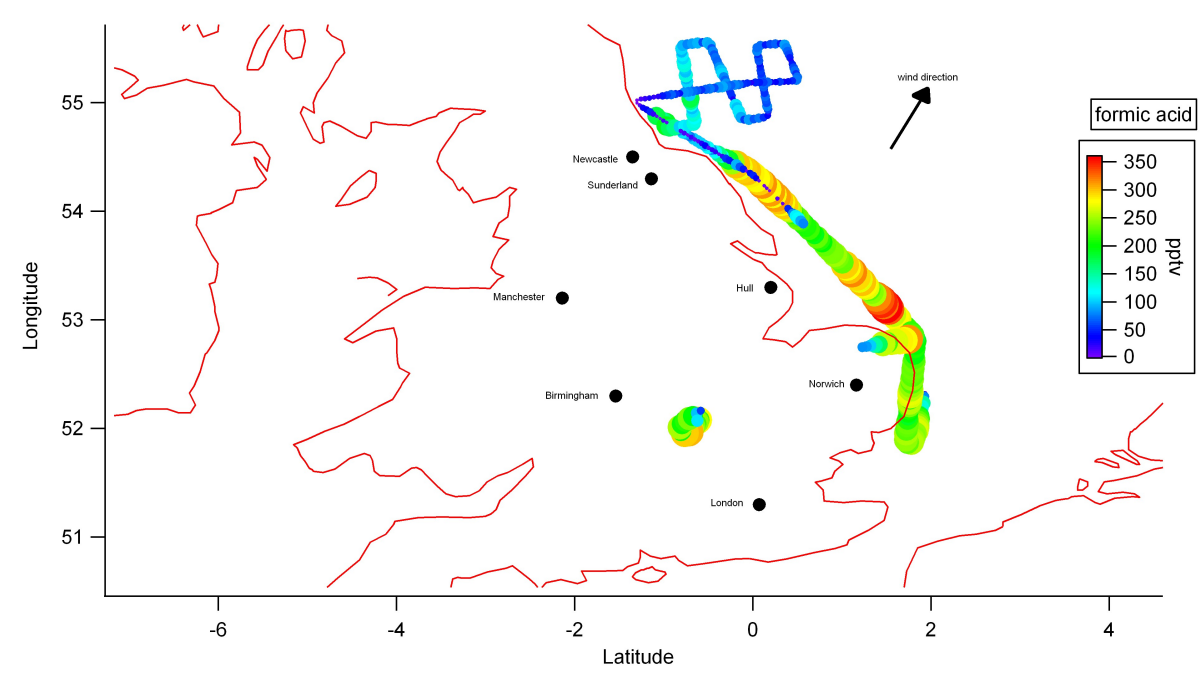

Fig. 5. The FAAM BAe-146 flight track on 16 March 2010 over the UK. Formic acid mixing ratios are reverse rainbow colour coded from $0 \mathrm{ppb}$ to $0.36 \mathrm{ppb}$. Populated urban areas are indicated and labelled.

are labelled in Fig. 4. The London, Humberside and Tyneside plumes had peak concentrations of 358, 311 and 192 pptv, respectively. The ability to detect these different source areas demonstrates the utility of the instrument for formic acid detection.

The highest formic acid concentration throughout the flight was measured from the London plume. The London metropolitan area is densely populated with a high volume of industrial, domestic and transport activity, a known major source of carboxylic acid emissions (Chebbi and Carlier, 1996). Kawamura and Kaplan (1985) observed formic acid emitted directly from motor vehicle exhausts, which our results show agreement with. The high volume of traffic in the Greater London region is likely to be a major source of formic acid. Important emissions from anthropogenic sources, such as motor exhausts' incomplete combustion of fuel, indicate high levels of formic acid should be emitted from the London area (Kawamura and Kaplan, 1985). Enol formation during combustion has also been noted as a potential source of organic acids (Archibald et al., 2007b). Flight B518 collected data passing through this region. Figure 5 shows the flight track and the concentrations observed on this day. The south-south-westerly wind direction allowed measurements of this plume at an altitude of $700 \mathrm{~m}, 230 \mathrm{~km}$ away from the source. With the average wind speed of $2.8 \mathrm{~m} \mathrm{~s}^{-1}$ on this day, the plume is estimated to have taken around $18 \mathrm{~h}$ to reach the location where the CIMS detected it (off the North Norfolk coast). The time series of formic acid concentrations indicates a peak mixing ratio of $358 \mathrm{pptv}$ over this region. No correlations were observed with $\mathrm{NO}_{\mathrm{x}}$ and $\mathrm{O}_{3}$, although $\mathrm{NO}_{\mathrm{x}}$ is known to be a marker of traffic and anthropogenic sources. However, restricting ourselves to just data known to be associated with a plume, a positive correlation between $\mathrm{CO}$ and $\mathrm{HCOOH}$ emerges (see Fig. 6). Although it is tempting to infer a primary source of $\mathrm{HCOOH}$ from urban environments,
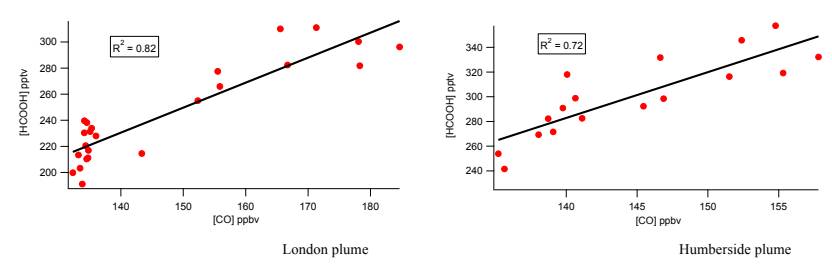

Fig. 6. Correlation plots of $\mathrm{HCOOH}$ vs. $\mathrm{CO}$ for the London and Humberside plumes.

it is also possible that these data infer that $\mathrm{HCOOH}$ precursors are emitted from urban areas and therefore correlate with $\mathrm{CO}$ (see later). The different formation and loss processes of $\mathrm{NO}_{\mathrm{x}}$ and formic acid may have different time constants, therefore producing a low correlation even if a strong primary emission of $\mathrm{HCOOH}$ exists. Since $\mathrm{CO}$ is effectively an inert tracer of pollution on the timescales considered here, a correlation with $\mathrm{HCOOH}$ is strong evidence of an urban source.

The second plume detected during the flight was from the Humberside region. This is an urban area but with lower population and industrial activity than London; the lower concentrations observed may reflect this difference, but dilution will also be a factor. North of latitude $53^{\circ} 50$, the average ambient mixing ratio drops to below $100 \mathrm{pptv}$, whereas an average concentration before this was 200 pptv. This low ambient concentration allowed the detection of a plume with a peak of 192 pptv from the Tyneside region (Fig. 7). Tyneside is expected to be a heavily polluted area similar to that of Humberside and with similar sources as London. The lower mixing ratios found in the Tyneside plume could be due to a number of reasons: lower direct emissions, lower precursor emissions, more aged plume, greater depositional loss, etc. More data are needed to identify and characterise important source regions over the UK. 


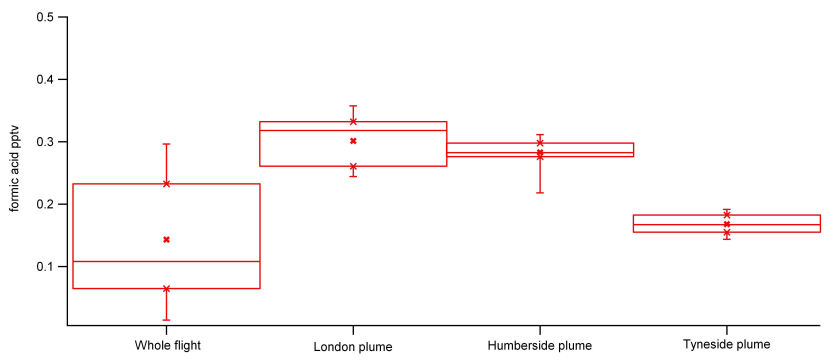

Fig. 7. Box and whisker plots of total flight data and individual plumes detected during flight B518. Whiskers indicate the 5th and 95th percentile.

\subsection{Altitude profile}

The correct altitude profile is essential for satellite retrievals and their inference regarding the photochemistry of formic acid. A vertical profile of formic acid from 800 to $2300 \mathrm{~m}$ is shown in Fig. 8. The concentration increases up to $1200 \mathrm{~m}$, peaking at a concentration of $313 \mathrm{pptv}$ and then falling off with increasing altitude. Low concentrations were observed below $1000 \mathrm{~m}$. Although Baboukas et al. (2000) observed emissions of formic acid from the ocean, net flux measurements are not well known. Emission rates during this flight may have been lower than the deposition rates, causing the observed lower concentrations. If the only source of formic acid was of primary origin from the surface, then, irrespective of depositional losses, we would imagine that the highest levels would be encountered at the surface and the mixing ratios decrease with altitude. However, it is of course possible to intercept polluted plumes at only higher altitudes and, relative to cleaner surface air, this would give rise to the observations reported. A further explanation of the peak observed at $\sim 1000 \mathrm{~m}$ is that there are significant secondary sources of formic acid, following oxidation of formic acid precursors within the plume. At $1000 \mathrm{~m}$, air masses rising from anthropogenic and/or biogenic sources (primary and secondary) will be far less susceptible to dry deposition, and so it is possible to imagine that the formic acid altitude profile goes through a maximum at this altitude. A decrease in concentration is observed at $2000 \mathrm{~m}$; this is effectively the top of the boundary layer, and this decrease may simply be dilution of these plumes. The profile in Fig. 8 was measured on the edge of the London plume. Despite the possible higher concentrations in the profile contributed by the plume, it can still provide information concerning the gas as a function of altitude, although it may not be typical of an ambient formic acid profile. Hence, the plume correlation between $\mathrm{CO}$ and $\mathrm{HCOOH}$ probably indicates that both primary emissions of $\mathrm{HCOOH}$ exist and also emissions of $\mathrm{HCOOH}$ precursors exist in the urban environment.

Reiner et al. (1999) measured formic acid in the UTLS (standard upper troposphere-lower stratosphere) region from $7-12 \mathrm{~km}$ and observed that formic acid concentrations

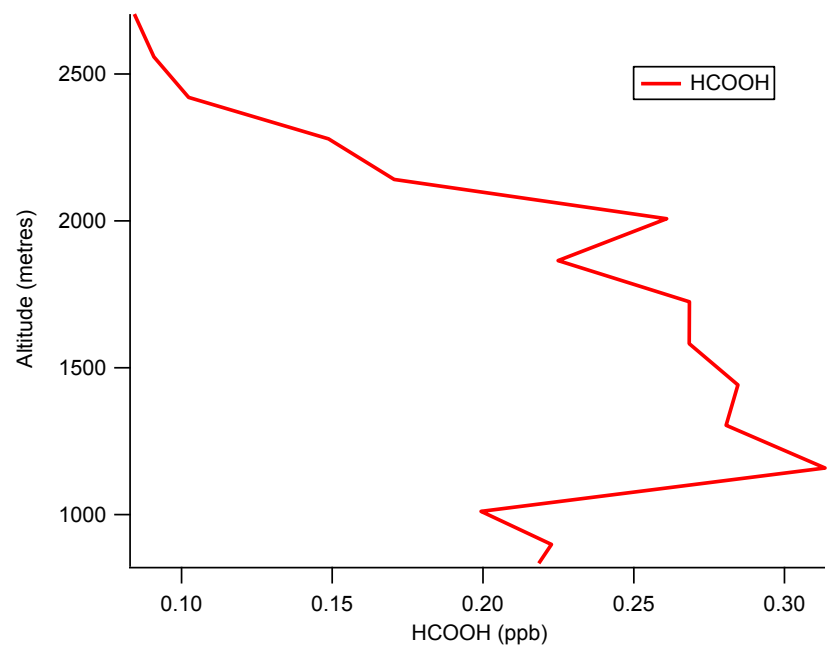

Fig. 8. Vertical profiles of formic acid and $\mathrm{NO}_{\mathrm{x}}$ mixing ratios from an altitude of 800 to $2300 \mathrm{~m}$.

decrease with altitude, which is in agreement with this work. The measured formic acid concentrations ranged from 0 $600 \mathrm{ppt}$, with mean concentrations of 59-215 pptv across the measured altitude range.

\subsection{Comparison between model and measurements}

The comparison between the trajectory model $\mathrm{CO}$ and $\mathrm{O}_{3}$ and the respective measurements is good, as shown in Fig. 9. The model slightly underestimates $\mathrm{O}_{3}$ and has a tendency to slightly overestimate $\mathrm{CO}$. We conclude that the dynamics and chemical processing components (oxidising capacity) of the model are operating correctly. If we assume that formic acid is being formed by in situ chemistry, then ozonolysis of 1alkenes should be the dominant source. Since the model $\mathrm{O}_{3}$ is reasonably well reproduced, we would conclude that where the model underestimates formic acid significantly (before ca. 02:00 p.m. LT), there is a shortage of 1-alkene precursors. As an example, assuming propene as the 1-alkene, model estimates suggest that an additional $2-5 \mathrm{ppb}$ is required in the model to generate the formic acid observed. Rather than a substantial omission of an emission of a species like propene, we suspect that lower levels of faster reacting 1-alkenes are missing from the model. It is perfectly possible for these fast reacting alkenes to be missing from inventories or for them to be represented by other alkenes that do not lead to formic acid formation. There is no suggestion in the measurement data or the model that a substantial biomass burning source is present at this time (March). A primary emission of $\mathrm{HCOOH}$ is also a strong possibility and would increase plume levels of $\mathrm{HCOOH}$.

Although the modelled concentrations do not show as large a variation as the measurements, there is a clear negative gradient with altitude, in keeping with the observations. The model underestimates measurements by a factor of two 


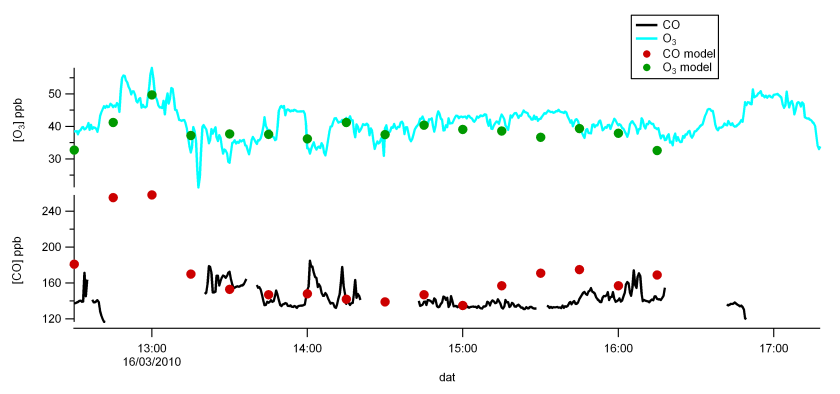

Fig. 9. Ozone and CO concentration time series from flight B518 with back trajectory modelled data.

up to around 02:30 p.m., and from then on agreement between the two is good (Fig. 4). The sources of formic acid in the model are the reaction of $\mathrm{CH}_{2} \mathrm{OO}$ (from ethene ozonolysis predominantly but also other sources such as isoprene) with water and the reaction of $\mathrm{OH}$ with acetylene, where the former represents over $95 \%$ of the production and the latter the remainder (Taatjes et al., 2008; Welz et al., 2012; Leather et al., 2012). Based on the biogenic emission inventory used, the level of primary emissions from biogenic hydrocarbons into these trajectories is low. The underprediction early on in the time series could be due to missing direct surface emissions or missing extremely reactive formic acid precursors (e.g. Archibald et al., 2007a) such as isoprene. Indeed, inspection of the trajectories shows that at around 02:00 p.m. the aircraft encountered air associated with the plumes from London and Humberside and would have picked up primary surface emissions from combustion sources. Measurements from around 03:00 p.m. onwards are lower; this is a result of an increase in altitude, where air mass back trajectories suggest that direct input from primary surface sources is much weaker. If ozonolysis of terminal olefinic species leads to the formation of $\mathrm{CH}_{2} \mathrm{OO}$ (Leather et al., 2012; Taatjes et al., 2008; Welz et al., 2012) and the Criegee intermediate reacts with water to form formic acid, there may be both anthropogenic and biogenic sources (e.g. isoprene and certain terpenes). Inspection of urban isoprene levels from the UK Air Quality (NETCEN) archive (e.g. Rivett et al., 2003a, b; Khan et al., 2008) show that typical levels in March are around $60 \mathrm{pptv}$, and not all of this will be of biogenic origin. Using these levels of surface isoprene (higher than those predicted by the emission model) as input into the trajectory model would not generate anywhere near enough formic acid to rectify the model underprediction that is seen up to around 02:30 p.m. Increasing primary morning emissions of formic acid from an anthropogenic source increases formic acid in the early afternoon, but has less effect in the late afternoon, consistent with observations. Therefore, based on such a simple analysis, the discrepancy early on is probably due to anthropogenic emissions, either from direct emissions of formic acid or emission of fast producing $\mathrm{HCOOH}$ precursors and their reaction with ozone. Therefore, we conclude that anthropogenic sources are probably responsible for the additional formic acid observed before 02:30 p.m., and such a conclusion is consistent with the correlation of $\mathrm{HCOOH}$ with $\mathrm{CO}$ in these plumes.

\section{Conclusions}

The first detailed formic acid measurements by chemical ionization mass spectrometer (CIMS) onboard an airborne platform using $\mathrm{I}^{-}$ionization chemistry are presented. The $\mathrm{I}^{-}$ ionization chemistry has been successfully employed for the detection and measurement of trace amounts of atmospheric formic acid. The sensitivity of CIMS in the detection of formic acid was $35 \pm 6$ ion counts s ${ }^{-1} \mathrm{pptv}^{-1}$, and the limit of detection was $25 \mathrm{pptv}$. Mean concentrations of formic acid in the UK boundary layer on 16 March 2010 were $142 \pm 72$ pptv. Higher concentrations were observed in plumes, which could be linked by trajectory analysis to main urban and industrial centres (London, Humberside and Tyneside regions). Formic acid showed no clear correlation with anthropogenic pollution markers such as $\mathrm{NO}_{\mathrm{x}}, \mathrm{CO}$ and $\mathrm{O}_{3}$. The highest formic acid mixing ratios were observed at $\sim 1000 \mathrm{~m}$; although this could arise from intercepting polluted plumes at higher altitudes only, it may also signal the presence of a significant secondary source of formic acid within the plume. Formic acid levels as estimated by a trajectory model showed an underprediction of concentrations by up to a factor of 2 . The model discrepancy can be resolved by the addition of 1alkene surface emissions that are oxidised to produce formic acid in situ or by addition of a direct emission of $\mathrm{HCOOH}$. Whether the source of the 1-alkene is of anthropogenic or biogenic origin is unclear. More measurements and in-depth modelling studies are needed to validate the current chemical transport models and help identify and quantify formic acid emission sources. This should also improve understanding of the role of formic acid in chemical cycling in the troposphere. Direct measurements of formic acid in the UK boundary layer have shown how variable formic acid levels can be, and that distinct plumes of formic acid can be identified in the horizontal and vertical. The inability of the model to reproduce the observations in the part of the flight before ca. 02:00 p.m. highlights that further studies must aim to improve the understanding and quantification of formic acid sources.

Acknowledgements. The authors would like to thank Alan Knights for analysing the organic acid calibration gas mixture by GC-FID ADS. FAAM staff are also thanked for their assistance in getting the CIMS working onboard the aircraft. CJP and DES thank NERC under whose auspices various elements of this work were carried out.

Edited by: H. Harder 


\section{References}

Amelynck, C., Schoon, N., and Arijs, E.: Gas phase reactions of $\mathrm{CF}_{3} \mathrm{O}$ - and $\mathrm{CF}_{3} \mathrm{O}-\mathrm{H}_{2} \mathrm{O}$ with nitric, formic, and acetic acid, Int. J. Mass Spectrom., 203, 165-175, 2000.

Archibald, A. T., McGillen, M. R., Taatjes, C. A., Percival, C. J., Shallcross, D. E.: Atmospheric transformation of enols: A potential secondary source of carboxylic acids in the urban troposphere, Geophys. Res. Lett., 34, L21801, doi:10.1029/2007GL031032, 2007a.

Archibald, A. T., McGillen, M. R., Taatjes, C. A., Percival C. J., and Shallcross, D. E.: On the importance of Ethenol in urban atmospheres, Geophys. Res. Lett., 34, L21801, doi:10.1029/2007GL031032, 2007b.

Archibald, A. T., Cooke, M. C., Utembe, S. R., Shallcross, D. E., Derwent, R. G., and Jenkin, M. E.: Impacts of mechanistic changes on $\mathrm{HO}_{\mathrm{x}}$ formation and recycling in the oxidation of isoprene, Atmos. Chem. Phys., 10, 8097-8118, doi:10.5194/acp-108097-2010, 2010.

Arlander, D. W., Cronn, D. R., Farmer, J. C., Menzia, F. A., and Westberg, H. H.: Gaseous oxygenated hydrocarbons in the remote marine troposphere, J. Geophys. Res.-Atmos., 95, 1639116403, 1990.

Baboukas, E. D., Kanakidou, M., and Mihalopoulos, N.: Carboxylic acids in gas and particulate phase above the Atlantic Ocean, J. Geophys. Res.-Atmos., 105, 14459-14471, 2000.

Bertram, T. H., Kimmel, J. R., Crisp, T. A., Ryder, O. S., Yatavelli, R. L. N., Thornton, J. A., Cubison, M. J., Gonin, M., and Worsnop, D. R.: A field-deployable, chemical ionization timeof-flight mass spectrometer, Atmos. Meas. Tech., 4, 1471-1479, doi:10.5194/amt-4-1471-2011, 2011.

Burling, I. R., Yokelson, R. J., Griffith, D. W. T., Johnson, T. J., Veres, P., Roberts, J. M., Warneke, C., Urbanski, S. P., Reardon, J., Weise, D. R., Hao, W. M., and de Gouw, J.: Laboratory measurements of trace gas emissions from biomass burning of fuel types from the southeastern and southwestern United States, Atmos. Chem. Phys., 10, 11115-11130, doi:10.5194/acp10-11115-2010, 2010.

Broadgate, W. J., Liss, P. S., and Penkett, S. A.: Seasonal emissions of isoprene and other reactive hydrocarbon gases from the ocean, Geophy. Res. Lett., 24, 2675-2678,1997.

Chebbi, A. and Carlier, P.: Carboxylic acids in the troposphere, occurrence, sources, and sinks: A review, Atmos. Environ., 30, 4233-4249, 1996.

Crounse, J. D., McKinney, K. A., Kwan, A. J., and Wennberg, P. O.: Measurement of gas-phase hydroperoxides by chemical ionization mass spectrometry, Anal. Chem., 78, 6726-6732, 2006.

de Gouw, J. A., Goldan, P. D., Warneke, C., Kuster, W. C., Roberts, J. M., Marchewka, M., Bertman, S. B., Pszenny, A. A. P., and Keene, W. C.: Validation of proton transfer reaction-mass spectrometry (PTR-MS) measurements of gas-phase organic compounds in the atmosphere during the New England Air Quality Study (NEAQS) in 2002, J. Geophys. Res., 108, 4682, doi:10.1029/2003JD003863, 2003.

Derwent, R. G. and Jenkin, M. E., Hydrocarbons and the long-range transport of ozone and PAN across Europe, Atmos. Environ., 30, 181-199, 1996.

Derwent, R. G., Jenkin, M. E., and Saunders, S. M.: Photochemical ozone creation potentials for a large number of reactive hydrocarbons under European conditions, Atmos. Environ., 25, 1661-
$1678,1991$.

Dibb, J. E., Talbot, R. W., Whitlow, S. I., Shipham, M. C., Winterle, J., McConnell, J., and Bales, R.: Biomass burning signatures in the atmosphere and snow at Summit, Greenland: An event on 5 August 1994, Atmos. Environ., 30, 553-561, 1996.

Draxler, R. R. and Rolph, G. D.: HYSPLIT (HYbrid Single-Particle Lagrangian Integrated Trajectory) Model access via NOAA ARL READY Website, available at: http://www.arl.noaa.gov/ready/ hysplit4.html (last access: 30 November 2012), NOAA Air Resources Laboratory, Silver Spring, MD, 2003.

Evans, M. J., Shallcross, D. E., Law, K. S., Wild, J. O. S., Simmonds, P. G., Spain, T. G., Berrisford, P., Methven, J., Lewis, A. C., McQuaid, J. B., Pilling, M. J., Bandy, B. J., Penkett, S. A., and Pyle, J.: Evaluation of a Lagrangian box model using field measurements from EASE (Eastern Atlantic Summer Experiment) 1996, JA, Atmos. Environ., 34, 3843-3863, 2000.

Fornaro, A. and Gutz, I. G. R.: Wet deposition and related atmospheric chemistry in the Sao Paulo metropolis, Brazil: Part 2 - contribution of formic and acetic acids, Atmos. Environ., 37, 117-128, 2003.

Gerbig, C., Schmitgen, S., Kley, D., and Volz-Thomas, A.: An improved fast-response vacuum-UV resonance fluorescence $\mathrm{CO}$ instrument, J. Geophys. Res., 104, 1699-1704, 1999.

González Abad, G., Bernath, P. F., Boone, C. D., McLeod, S. D., Manney, G. L., and Toon, G. C.: Global distribution of upper tropospheric formic acid from the ACE-FTS, Atmos. Chem. Phys., 9, 8039-8047, doi:10.5194/acp-9-8039-2009, 2009.

Granby, K., Christensen, C., and Lohse, C.: Urban and semi-rural observations of carboxylic acids and carbonyls, Atmos. Environ., 31, 1403-1415, 1997.

Grosjean, D.: Formic acid and acetic acid emissions, atmopsheric formication and dry seposition at 2 southern California locations, Atmos. Environ., 26, 3279-3286, 1992.

Grosjean, D. and Seinfeld, J. H.: Parameterization of the formation potential of secondary organic aerosols, Atmos. Environ., 23, 1733-1747, 1989.

Hartmann, W. R., Santana, M., Hermoso, M., Andreae, M. O., and Sanhueza, E.: Diurnal cycles of formic and acetic acids in the northern part of the Guayana shield, Venezuela, J. Atmos. Chem., 13, 63-72, 1991.

Jacob, D.: Chemistry of $\mathrm{OH}$ in remote clouds and its role in the production of formic acid and peroxymonosulfate, J. Geophys. Res., 91, 9807-9826, 1986.

Jenkin, M. E., Saunders, S. M., Derwent, R. G., and Pilling, M. J.: Construction and application of a master chemical mechanism (MCM) for modelling tropospheric chemistry, Abstr. Pap. Am. Chem. S., 214, p. 116, 1997.

Jenkin, M. E., Watson, L. A., Utembe, S. R., and Shallcross, D. E.: A Common Representative Intermediates (CRI) mechanism for VOC degradation. Part 1: Gas phase mechanism development, Atmos. Environ., 42, 7185-7195, 2008.

Johnson, B. J. and Dawson, G. A.: A preliminary study of the carbon isotopic content of ambient formic acid and 2 selected sources - automobile exhaust and formicine ants, J. Atmos. Chem., 17, 123-140, 1993.

Johnson, D., Utembe, S. R., Jenkin, M. E., Derwent, R. G., Hayman, G. D., Alfarra, M. R., Coe, H., and McFiggans, G.: Simulating regional scale secondary organic aerosol formation during the TORCH 2003 campaign in the southern UK, Atmos. Chem. 
Phys., 6, 403-418, doi:10.5194/acp-6-403-2006, 2006 a.

Johnson, D., Utembe, S. R., and Jenkin, M. E.: Simulating the detailed chemical composition of secondary organic aerosol formed on a regional scale during the TORCH 2003 campaign in the southern UK, Atmos. Chem. Phys., 6, 419-431, doi:10.5194/acp-6-419-2006, 2006b.

Kawamura, K. and Kaplan, I. R.: Determination of organic acids (CrC10) in the atmosphere, motor exhausts, and engine oils, Environ. Sci. Technol., 19, 1082-1086, 1985.

Keene, W. C. and Galloway, J. N.: Considerations regarding sources of formic and acetic acids in the troposphere, J. Geophys. Res.Atmos., 91, 14466-14474, 1986.

Keene, W. C., Galloway, J. N., and Holden, J. D.: Measurement of weak organic acidity in precipitation from remote areas of the world, J. Geophys. Res.-Atmos., 88, 5122-5130, 1983.

Khan, M. A. H., Ashfold, M. J., Nickless, G., Martin, D., Watson, L. A., Hamer, P. D., Wayne, R. P., Canosa-Mas, C. E., and Shallcross, D. E.: Night-time $\mathrm{NO}_{3}$ and $\mathrm{OH}$ radical concentrations in the United Kingdom inferred from hydrocarbon measurements, Atmos. Sci. Lett., 9, 140-146, 2008.

Leather, K. E., McGillen, M. R., Cooke, M. C., Utembe, S. R., Archibald, A. T., Jenkin, M. E., Derwent, R. G., Shallcross, D. E., and Percival, C. J.: Acid-yield measurements of the gas-phase ozonolysis of ethene as a function of humidity using Chemical Ionisation Mass Spectrometry (CIMS), Atmos. Chem. Phys., 12, 469-479, doi:10.5194/acp-12-469-2012, 2012.

Nowak, J. B., Neuman, J. A., Kozai, K., Huey, L. G., Tanner, D. J., Holloway, J. S., Ryerson, T. B., Frost, G. J., McKeen, S. A., and Fehsenfeld, F. C.: A chemical ionization mass spectrometry technique for airborne measurements of ammonia, J. Geophys. Res.-Atmos., 112, D10S02, doi:10.1029/2006JD007589, 2007.

Paulot, F., Crounse, J. D., Kjaergaard, H. G., Kroll, J. H., Seinfeld, J. H., and Wennberg, P. O.: Isoprene photooxidation: new insights into the production of acids and organic nitrates, Atmos. Chem. Phys., 9, 1479-1501, doi:10.5194/acp-9-1479-2009, 2009a.

Paulot, F., Crounse, J. D., Kjaergaard, H. G., Kurten, A., St Clair, J. M., Seinfeld, J. H., and Wennberg, P. O.: Unexpected Epoxide Formation in the Gas-Phase Photooxidation of Isoprene, Science, 325, 730-733, 2009b.

Paulot, F., Wunch, D., Crounse, J. D., Toon, G. C., Millet, D. B., DeCarlo, P. F., Vigouroux, C., Deutscher, N. M., González Abad, G., Notholt, J., Warneke, T., Hannigan, J. W., Warneke, C., de Gouw, J. A., Dunlea, E. J., De Mazière, M., Griffith, D. W. T., Bernath, P., Jimenez, J. L., and Wennberg, P. O.: Importance of secondary sources in the atmospheric budgets of formic and acetic acids, Atmos. Chem. Phys., 11, 1989-2013, doi:10.5194/acp-11-1989-2011, 2011.

Preunkert, S., Legrand, M., Jourdain, B., and DombrowskiEtchevers, I.: Acidic gases $\left(\mathrm{HCOOH}, \mathrm{CH}_{3} \mathrm{COOH}, \mathrm{HNO}_{3}, \mathrm{HCl}\right.$, and $\mathrm{SO}_{2}$ ) and related aerosol species at a high mountain Alpine site (4360 m elevation) in Europe, J. Geophys. Res.-Atmos., 112, D23S12, doi:10.1029/2006JD008225, 2007.

Real, E., Law, K. S., Weinzierl, B., Fiebig, M., Petzold, A., Wild, O., Methven, J., Arnold, S., Stohl, A., Huntrieser, H., Roiger, A., Schlager, H., Stewart, D., Avery, M., Sachse, G., Browell, E., Ferrare, R., and Blake, D.: Processes influencing ozone levels in Alaskan forest fire plumes during long-range transport over the North Atlantic, J. Geophys. Res.-Atmos., 112, D10S41, doi:10.1029/2006JD007576, 2007.
Reiner, T., Mohler, O., and Arnold, F.: Measurements of acetone, acetic acid, and formic acid in the northern midlatitude upper troposphere and lower stratosphere, J. Geophys. Res.-Atmos, 104, 13943-13952, 1999.

Rinsland, C. P., Mahieu, E., Zander, R., Goldman, A., Wood, S., and Chiou, L.: Free tropospheric measurements of formic acid (HCOOH) from infrared ground-based solar absorption spectra: Retrieval approach, evidence for a seasonal cycle, and comparison with model calculations, J. Geophys. Res.-Atmos, 109, D18308, doi:10.1029/2004JD004917, 2004.

Rivett, A. C., Martin, D., Gray, D. J., Price, C. S., Nickless, G., Simmonds, P. G., O’Doherty, S. J., Greally, B. R., Knights, A., and Shallcross, D. E.: The role of volatile organic compounds in the polluted urban atmosphere of Bristol, England, Atmos. Chem. Phys., 3, 1165-1176, doi:10.5194/acp-3-1165-2003, 2003a.

Rivett, A. C., Martin, D., Nickless, G., Simmonds, P. G., O’Doherty, S. J., Gray, D. J., and Shallcross, D. E.: In situ gas chromatographic measurements of halocarbons in an urban environment, Atmos. Environ., 37, 2221-2235, 2003b.

Roberts, J. M., Veres, P., Warneke, C., Neuman, J. A., Washenfelder, R. A., Brown, S. S., Baasandorj, M., Burkholder, J. B., Burling, I. R., Johnson, T. J., Yokelson, R. J., and de Gouw, J.: Measurement of HONO, HNCO, and other inorganic acids by negative-ion proton-transfer chemical-ionization mass spectrometry (NI-PT-CIMS): application to biomass burning emissions, Atmos. Meas. Tech., 3, 981-990, doi:10.5194/amt-3-981-2010, 2010.

Roberts, J. M., Veres, P., Cochran, A. K., Warneke, C., Baasandorj, M., Burkholder, J. B., Burling, I. R., Johnson, T. J., Yokelson, R. J., and deGuow, J.: Isocyanic acid in the atmosphere and its possible link to smoke-related health effects, P. Natl. Acad. Sci., 108, 8966-8971, 2011.

Sanhueza, E. and Andreae, M. O.: Emissions of formic and acetic acids from tropical Savanna soils, Geophys. Res. Lett., 18, 17071710, 1991.

Sanhueza, E., Figueroa, L., and Santana, M.: Atmospheric formic and acetic acids in Venezuela, Atmos. Environ., 30, 1861-1873, 1996.

Slusher, D. L., Huey, L. G., Tanner, D. J., Flocke, F. M., and Roberts, J. M.: A thermal dissociation-chemical ionization mass spectrometry (TD-CIMS) technique for the simultaneous measurement of peroxyacyl nitrates and dinitrogen pentoxide, J. Geophys. Res.-Atmos., 109, D19315, doi:10.1029/2004JD004670, 2004.

Stewart, D. J., Taylor, C. M., Reeves, C. E., and McQuaid, J. B.: Biogenic nitrogen oxide emissions from soils: impact on $\mathrm{NO}_{\mathrm{X}}$ and ozone over west Africa during AMMA (African Monsoon Multidisciplinary Analysis): observational study, Atmos. Chem. Phys., 8, 2285-2297, doi:10.5194/acp-8-2285-2008, 2008.

Taatjes, C. A., Meloni, G., Selby, T. M., Trevitt, A. J., Osborn, D. L., Percival, C. J., and Shallcross, D. E.: Direct observation of the gas-phase Criegee intermediate $\left(\mathrm{CH}_{2} \mathrm{OO}\right)$, J. Am. Chem. Soc., 130, 11883-11885, 2008.

Talbot, R. W., Beecher, K., and Harriss, R.: Atmospheric geochemistry of formic and acetic acids at a mid-latitude temperate site, J. Geophys. Res., 93, 1638-1652, 1988.

Talbot, R. W., Mosher, B. W., Heikes, B. G., Jacob, D. J., Munger, J. W., Daube, B. C., Keene, W. C., Maben, J. R., and Artz, R. S.: Carboxylic acids in the rural continental atmosphere over the 
eastern United States during the Shenandoah cloud and photochemistry experiment. J. Geophys. Res., 100, 9335-9343, 1995.

Talbot, R. W., Dibb, J. E., Scheuer, E. M., Blake, D. R., Blake, N. J., Gregory, G. L., Sachse, G. W., Bradshaw, J. D., Sandholm, S. T., and Singh, H. B.: Influence of biomass combustion emissions on the distribution of acidic trace gases over the southern Pacific basin during austral springtime, J. Geophys. Res.-Atmos., 104, 5623-5634, 1999.

Veres, P., Roberts, J. M., Warneke, C., Welsh-Bon, D., Zahniser, M., Herndon, S., Fall, R., and de Gouw, J.: Development of negativeion proton-transfer chemical-ionization mass spectrometry (NIPT-CIMS) for the measurement of gas-phase organic acids in the atmosphere, Int. J. Mass Spectrom., 274, 48-55, 2008.

Von Kuhlmann, R., Lawrence, M. G., Crutzen, P. J., and Rasch, P. J.: A model for studies of tropospheric ozone and nonmethane hydrocarbons: Model evaluation of ozone-related species, J. Geophys. Res.-Atmos, 108, 4729, doi:10.1029/2002JD003348, 2003.

Utembe, S. R., Watson, L. A., Shallcross, D. E., and Jenkin, M. E.: A Common Representative Intermediates (CRI) mechanism for VOC degradation. Part 3: Development of a secondary organic aerosol module, Atmos. Environ., 43, 1982-1990, 2009.

Utembe, S. R., Cooke, M. C., Archibald, A. T., Jenkin, M. E., Derwent, R. J., and Shallcross, D. E.: Using a reduced Common Representative Intermediates (CRIv2-R5) mechanism to simulate tropospheric ozone in a 3-D Lagrangian chemistry transport model, Atmos. Environ., 44, 1609-1622, 2011a.

Utembe, S. R., Cooke, M. C., Archibald, A. T., Shallcross, D. E., Derwent, R. G., and Jenkin, M. E.: Simulating Secondary Organic Aerosol in a 3-D Lagrangian Chemistry Transport Model using the reduced Common Representative Intermediates Mechanism (CRIv2-R5), Atmos. Environ., 45, 1604-1614, 2011 b.
Watson, L. A., Shallcross, D. E., Utembe, S. R., and Jenkin, M. E.: A Common Representative Intermediates (CRI) mechanism for VOC degradation. Part 2: Gas phase mechanism reduction, Atmos. Environ., 42, 7196-7204, 2008.

Welz, O., Savee, J. D., Osborn, D. L., Vasu, S., Percival, C. J., Shallcross, D. E., and Taatjes, C. A.: Reaction of $\mathrm{CH}_{2} \mathrm{I}$ with $\mathrm{O}_{2}$ forms Criegee Intermediate: Direct Measurements of $\mathrm{CH}_{2} \mathrm{OO}$ Kinetics, Science, 335, 204-207, 2012.

Yates, E. L., Derwent, R. G., Simmonds, P. G., Greally, B. R., O'Doherty, S., and Shallcross, D. E.: The seasonal cycles and photochemistry of C2-C5 alkanes at Mace Head, Atmos. Environ., 44, 2705-2713, 2010.

Yu, S. C.: Role of organic acids (formic, acetic, pyruvic and oxalic) in the formation of cloud condensation nuclei $(\mathrm{CCN})$ : a review, Atmos. Res., 53, 185-217, 2000.

Zander, R., Duchatelet, P., Mahieu, E., Demouli, P., Roland, G., Servais, C., Vander Auwera, J., Perrin, A., Rinsland, C. P., and Crutzen, P.: Formic acid above the Jungfraujoch during 19852007: observed variability, seasonality, but no long-term background evolution, J. Atmos. Chem. Phys., 10, 10047-10065, 2010 , http://www.atmos-chem-phys.net/10/10047/2010/.

Zhong, Z. C., Victor, T., and Balasubramanian, R.: Measurement of major organic acids in rainwater in Southeast Asia during burning and non-burning period, Water Air Soil Poll., 130, 457-462, 2001. 